ОСОБЛИВОСТІ РОЗВИТКУ

СВІТОВОГО ГОСПОДАРСТВА ТА МЕВ

УДК 339

\title{
PRINCIPLES AND INSTRUMENTS OF INTERNATIONAL ENVIRONMENTAL POLICY
}

\section{ПРИНЦИПИ ТА ІНСТРУМЕНТИ МІЖНАРОДНОЇ ЕКОЛОГІЧНОЇ ПОЛІТИКИ}

\section{ПРНЦИПЫ И ИНСТРУМЕНТЫ МЕЖДУНАРОДНОЙ ЭКОЛОГИЧЕСКОЙ ПОЛИТИКИ}

\author{
Anton S. Filipenko \\ Doctor of Economics, Professor, Professor of the Department of World Economy and International Economic \\ Relations of the Institute of International Relations of Taras Shevchenko National University of Kyiv. E-mail: \\ anton_filipenko@ukr.net
}

\section{Антон Сергійович Філіпенко}

Доктор економічних наук, професор, професор кафедри світового господарства i міжнародних економічних відносин Інституту міжнародних відносин Київського національного університету імені Тараса Шевченка. E-mail: anton_filipenko@ukr.net

\section{Антон Сергеевич Филипенко}

Доктор экономических наук, професор, профессор кафедры мирового хозяйства и международных экономических отношений Инстити тута международных отношений Киевского национального университета имени Тараса Шевченко. E-mail: anton_filipenko@ukr.net

\begin{abstract}
The article analyses main principles and mechanism of international environmental policy of the different economic levels. Particularly is evaluated the role of United Nations, European Union and national states in framework of sustainable concept of economic development and Millennium development goals. Are used market-based instruments such as taxes, subsidies and certificates, quantitative methods of regulation; government spending on public goods, environmental investments (e.g. water pollution) and planning environmental education etc. Among the institutional instruments of the international environmental policy are first of all three types of international agreements depending of deploying of situation in global environment. The focus of main environmental problems, according to the OECD / Eurostat classification, include air pollution control, water management, solid waste management, soil remediation and purification, noise reduction and vibration, environmental research and development, environmental commitments and engineering, analytical services, data processing, analysis and evaluation, education, training, and information.
\end{abstract}

Key words: international environmental policy, sustainable development, principles, instruments, agreement, ecological goods.

Анотація. У статті аналізуються основні принципи та механізми міжнародної екологічної політики на різних економічних рівнях. Зокрема, досліджується роль Організащії Об”єднаних Начій, Європейського Союзу та нащіональних держав у контексті реалізачії конщепції сталого економічного розвитку, Цілей тисячоліття розвитку. Використано такі ринкові інструменти, як податки, субсидії, сертифікати, кількісні методи регулювання, державні витрати на соціальні товари, 
екологічні інвестиції (наприклад, забруднення води), планування екологічної освіти тощзо. Серед інституиійних інструментів міжнародної екологічної політики першочергове значення мають три типи міжнародних угод, зумовлених ситуацією у глобальному екологічному середовищі. Акцентується увага на головних екологічних проблемах, які, згідно з класифікацією ОЕСР та Свростату, включають у себе контроль за забрудненням повітря, управління водними ресурсами та відходами, очищення та відновлення земельних ресурсів, скорочення шуму і вібращій, дослідження $i$ розвиток екологічних питань, зобов"язання та інжиніринг з довкілля, аналітичні послуги, обробку даних, аналіз і оцінку, освіту, тренінги та інформацію.

Ключові слова: міжнародна екологічна політика, сталий розвиток, принциии, інструменти, угода, екологічні товари.

Аннотация., обработку данных, анализ и оценку, образование, тренинги и информацию. В статье анализируются принципь и механизмь международной экологической политики на различных экономических уровнях. В частности, исследуется роль Организаџии Объединенных Наџий, Европейского Союза, национальных держав в контексте реализации конщепџии устойчивого развития, Целей тысячелетия развития. Использованы такие рыночные инструменты, как налоги, субсидии, сертификаты, количественные методы регулирования, государственные расходыл на сочиальные товары, экологические инвестиции (например, загрязнение воды), планирование экологического просвещения и др. Среди институциональных инструментов международной экологической политики приоритетное значение имеют три типь международных соглашений, подписываемых в зависимости от состояния глобального экологического пространства. Обращается внимание на главные экологические проблемы, которые согласно ОЭСР и Евростата, включают в себя контроль за загрязнением воздуха, управление водными ресурсами и отходами, очистку и возобновление земельньх ресурсов, сокращение шума и вибращий, исследование и развитие экологических вопросов, обязательства и инжиниринг, аналитические услуги

Ключевые слова: международная экологическая политика, устойчивое развитие, принципы, инструменты, соглашение, экологические товары.

Current problems. Environmental policy is an integral part of sustainable economic development, and its principal aim is to meet the needs of the current generation without compromising the capabilities of future generations. The environment and its features constitute a significant factor in the present-day economic progress, giving a "greener" look to the international economic policy.

Environmental policy covers a variety of national and international laws and regulations on environmental protection, including those addressing the issues of air and water pollution, global warming, depletion of renewable and non-renewable natural resources, the disappearance of endangered species, destruction (loss) of the natural habitat, the use of genetically modified organisms (GMOs) [Smith, 2014: 215].

At the current stage, environmental policy gains a global dimension (for instance, the issues of climate change, biodiversity loss, etc.) and this international context determines its aims and objectives.

The Aim of the article is to describe the principles, mechanism and instruments of international environmental policy on national, geo-regional and global levels. Also is important to analyse institutional framework of the international environmental policy and criteria for policy evaluation. Particularly the major International Environmental Agreements have to consider.

Important research results. In 1992, the United Nations World Summit in Rio de Janeiro adopted Agenda 21 and the framework of the Convention on Climate Change. In 
1997, quantitative goals were set in Kyoto (92 \% reduction in GHG emissions by 2012 compared to 1990). In December 2011, at the United Nations Climate Conference in Durban, the road map for the Climate Change Agreement was developed and an agreement was reached to amend the Kyoto Protocol on new greenhouse gas emission reductions by 2017 or 2020. The Paris Climate Change Agreement was adopted in 2015 and ratified in 2016. In November 2016, Marrakesh, Morocco, hosted the $22^{\text {nd }}$ Conference of the Parties to the United Nations Framework Convention on Climate Change. Starting in 2020, the Global Climate Fund will allocate $€ 100$ billion annually for climate conservation and protection projects. At the same time, the US President Donald Trump decides on the country's withdrawal from Paris Climate Agreement.

The EU principles of environmental policy and its main objectives are formulated in the European Strategy for Sustainable Development of 2006 and in the new Europe 2020 Strategy. The overall objectives of sustainable growth, efficient and sustainable use of resources, and the development of a competitive low carbon economy are complemented by a number of environmental measures (emission reductions, biodiversity, the development of new, environmentally sound technologies), the creation of effective intellectual networks, the improvement of conditions for small and medium-sized businesses, and changes in consumer behavior.

Environmental policy rests on the following principles:

The polluter pays principle. In accordance with this principle, the polluter is always responsible for the cause of the damage (e.g. road tolls).

The equity principle. It applies in case when the polluter pays principle cannot be imposed. Similarly, the state or local community charges for damage to the environment (e.g. the destruction of the ozone layer).

The precautionary principle. This principle implies taking preventive measures, thus avoiding further damage (e.g., reforestation following the damage caused by an avalanche).

The participation principle. This is approach where the responsibility of the parties stems from design and implementation of common environmental policies (e.g. the environmental education).

These principles are implemented through appropriate instruments that combine environmental and economic efficiency.

Pigovian tax. This principle refers to taxes caused by the difference between the respective private and public (social) costs. Thus, the said tax applies in individual cases related to the endamagement of the environment, and only in a socially justified and socially weighted expression. Its main challenge consists in the identification and monetary assessment of environmental damage. Large amount of information is required to measure the degree of damage, its spatial and temporal framework, which will then determine the appropriate tax rate.

Principle of negotiation. This approach stems from the lack of accurate definition of environmental property rights. Due to unclear distribution of environmental rights of polluters and victims, the negotiations help them reach a certain socially acceptable level of pollution. The state's obligation here is to create and secure a viable negotiation and legal system. However, it is worth noting that the negotiations may also encompass operating costs, information, and strategic behavior, which may ultimately lead to a prisoner's dilemma.

Principle of legal liability. According to this approach, the polluter will be forced to pay damages. This entails additional public spending. Unlike the similar principle of the Pigovian tax, this principle depends on the nature of the liability (a debt obligation that arises only when the terms of the obligation are violated or the strict liability, in which all subsequent losses must be paid) and the degree, to which social costs are taken into account separately. In addition, additional public expenditures are needed to ensure the functioning of the state institution. On the one hand, damage can often not be measured accurately, and thus it is not possible to ensure recovery of damage from the polluter. On the other hand, the risk of 
contamination can lead to insufficient use of environmental resources [Kronberger/Hofer, 2012: 195].

Overall, the main instruments of environmental policy include regulatory frameworks, taxes, subsidies, tradable permits, voluntary approaches, and information-based incentives [OECD Environmental Outlook to 2030, 2008: 434-435]. They are used in various combinations in order to ensure the highest environmental impact and optimal costeffectiveness.

Thus, the principles and mechanisms of environmental policy comprise the following components:

- a regulatory framework that determines what is allowed and what is prohibited in the context of environmental protection;

- market-based instruments such as taxes, subsidies and certificates that intervene with price or quantitative methods of regulation;

- public spending on public goods, such as environmental investments (e.g. water pollution) and planning (e.g. greening);

- environmental education, i.e. dissemination of information, provision of consultations and trainings.

Since environmental policy is a global challenge in many areas (for example, climate change, biodiversity loss, depletion of the ozone layer, etc.), international conventions and institutions regulating these issues are important and necessary. Environment is an extremely heterogeneous and complex systemic structure that requires the development and implementation of large and diverse environmental projects with the participation of various stakeholders.

Agenda 21 clearly demonstrated some of major some difficulties and obstacles to the implementation of environmental initiatives. The United Nations organized the World Summit known as Earth Summit in 1992 in Rio (Brazil) to address these key issues with the largest number of participants. Several thousand people attended the summit - including numerous representatives from various NGOs. As a result, a political and environmental action plan and the Framework Convention on Climate Change (UNFCCC) were adopted. In 2002, the World Summit on Sustainable Development held in Johannesburg, saw the quantitative targets first used for the first time (e.g. a halving of the proportion of people without access to clean water and sanitation).

The United Nations Climate Change Conference is another central global initiative, held annually. New priority objectives as well as targets for emission reduction were negotiated within the framework of the Convention on Climate Change. At the flagship conference in Kyoto in 1997, the Kyoto Protocol (in force since 16/02/2005) was developed with a commitment to reduce greenhouse gas emissions (in the EU, the overall decline in average values between 2008 and 2012 corresponds to $92 \%$ compared to 1990).

The main tools for implementing the provisions of the Kyoto Protocol are, on the one hand, tradable emission quotas provided that they are introduced between countries, and, on the other hand, countries that implement emission-reduction projects in other countries (either through 'Joint Implementation' in countries that have commitments for emission reductions, or through the 'Clean Development Mechanism' in the developing countries) earn credits for retained emissions (Table 1).

Agreement, known as the successor to the Kyoto Protocol approved at a conference in Copenhagen in 2009, aims at limiting the effects of global warming. Even greater results have been achieved due to the goals set out in the section of the UN Climate Conference held in December 2011 in Durban, along with the Road Map for the Climate Agreement, the key agreement on the extension of the Kyoto Protocol and other provisions on the Global Climate Fund. 


\section{Fragment from the Kyoto Protocol on National Emissions Trading}

\begin{tabular}{|c|c|l|}
\hline \multicolumn{3}{|c|}{$\begin{array}{c}\text { Distribution of emissions reductions by EU } \\
\text { member countries, } \%\end{array}$} \\
\hline Luxembourg: -28 & Italy: $-6,5$ & Spain: +15 \\
\hline Denmark: -21 & France: +-0 & Greece: +25 \\
\hline Germany: -21 & Sweden: +4 & Portugal: +27 \\
\hline Austria: -13 & Ireland: +13 & \\
\hline
\end{tabular}

Source: [Kronberger/Hofer, 2012: 203]

The Kyoto Protocol was fundamentally a market-based instrument, i.e. a certificate (tradable property right), effective in the field of environmental policy. However, its ultimate goal, a significant reduction in emissions, was not achieved. Not all industries and not all CO2 productions have been integrated into emissions trading. The environmental policy toolkit was used in the European Semester as well as in the national reform programs. One should also mention the initiative on a unified European System of Environmental Information (EUEI) proposed in February 2008. It also includes the Geospatial and Global Environment and Security Monitoring and integrates them with the Global Earth Observation System of Systems (GEOSS).

The established institutions and measures they propose are aimed at improving environmental policy-making. However, their real impact will be assessed much later.

In recent years, especially at the European level and in the frameworks of OECD, the term eco-innovation is used to refer to the technological advancement in the field of environmental technology, which is a key element that opens the way to establishing a balance between economic growth and environmental burden.

\section{Institutional framework of the international environmental policy}

The efforts of international community in the area of environmental protection traditionally cover two main periods: the first period lasted from 1960 to 1990; the second period started in 1990 and continues to the present days.

There are three types of international environmental agreements. The first type concerned the protection of deserts and wildlife and covered such agreements as the Pacific Fur Agreement (1911) and the International Convention on the Regulation of Whaling (1946). The second type of agreement was aimed at regulating marine pollution and was embodied in the International Convention for the Prevention of Oil Pollution from the Sea (1954) and the Convention on the High Seas (1958). The third category of environmental agreements comprised agreements limiting the proliferation of nuclear weapons, which were enshrined in the Antarctic Treaty (1959) and the Treaty on the Prohibition of Testing of Nuclear Weapons in the Atmosphere, Outer Space and Underwater (1963). These treaties were important, but they were not part of an integrated environmental protection system.

In the early 1970s, the OECD countries approved the principles of payments for pollution, which concerned exclusively domestic pollution. These principles stipulate that the polluter shall reimburse the cost of pollution-reduction measures. In connection with the overly general nature of these principles and the development of transboundary pollution, the United Nations has recommended the adoption of multilateral compensation principles.

The first major UN conference on human rights issues (UNSEGE) was held in Stockholm in 1972. Following the conference, the Stockholm Declaration adopted 26 principles, an action plan containing 109 recommendations, and established the United Nations Environment Program (UNEP).

The United Nations Conference on Environment and Development (UNCED) was the result of the decisions taken by the Rio Summit in Rio de Janeiro (1992). 
The WTO Ministerial Conference, held in Doha in November 2001, called for the preparation of multilateral environmental agreements ${ }^{1}$.[Lee, 2012: 343]. It referred to the harmonization of principles, norms, rules and obligations of the WTO and corresponding provisions, stipulated in multilateral agreements on the environment. In particular, it concerned the Convention on Biological Diversity, the Montreal Protocol on Substances that Deplete the Ozone Layer, the Basel Convention on the Control of Transboundary Movements of Hazardous Wastes and their Disposal, and the United Nations Framework Convention on Climate Change. Due to the presence of certain differences and conflicting positions in multilateral agreements and WTO agreements related to trade and the environment, a decision was taken to establish an advisory mechanism in the WTO with a view to reconciling the positions among countries.

Two WTO environmental protection instruments regulate environmental issues, as well as human and animal and plant life and health. This is the Agreement on Technical Barriers to Trade and the Agreement on the Application of Sanitary and Phytosanitary Measures.

Agreement on Application of Sanitary and Phytosanitary Measures is devoted to the protection of humans, animals and plants from the risks to their lives and health, including the risks of additives, contamination or food toxins.

The Agreement on Technical Barriers to Trade refers to voluntary and mandatory standards for products that are not defined as sanitary or phytosanitary measures under the previous Agreement [Lee, 2012: 348-349]. Table 2 gives an overview of the main international environmental conventions.

Table 2

Major International Environmental Agreements

\begin{tabular}{|l|c|c|c|}
\hline \multicolumn{1}{|c|}{ Name of agreement } & $\begin{array}{c}\text { Date of } \\
\text { signing }\end{array}$ & $\begin{array}{l}\text { Date of } \\
\text { coming } \\
\text { into force }\end{array}$ & Web address \\
\hline $\begin{array}{l}\text { International Convention on the } \\
\text { Regulation of Whaling }\end{array}$ & 1946 & 1948 & www.iwcoffice.org \\
\hline $\begin{array}{l}\text { Convention on Wetlands of International } \\
\text { Importance, primarily as a Waterfowl } \\
\text { Habitat (Ramsar Convention) }\end{array}$ & 1971 & 1975 & www.ramsar.org \\
\hline $\begin{array}{l}\text { Convention on the Prevention of Marine } \\
\text { Pollution by Waste and Other Materials } \\
\text { (London Convention) }\end{array}$ & 1972 & 1975 & $\underline{\text { www.imo.org }}$ \\
\hline $\begin{array}{l}\text { Convention on International Trade in } \\
\text { Endangered Species of Wild Fauna and } \\
\text { Flora (CITES) }\end{array}$ & 1973 & 1975 & $\underline{\text { www.cites.org }}$ \\
\hline $\begin{array}{l}\text { Convention on the Conservation of } \\
\text { Antarctic Marine Living Resources }\end{array}$ & 1980 & 1982 & $\underline{\text { www.ccamlr.org }}$ \\
\hline $\begin{array}{l}\text { Montreal Protocol on Substances that } \\
\text { Deplete the Ozone Layer }\end{array}$ & 1987 & 1989 & $\underline{\text { www.ozone.unep.org }}$ \\
\hline $\begin{array}{l}\text { Basel Convention on the Control of } \\
\text { Transboundary Movements of Hazardous } \\
\text { Wastes and Their Disposal }\end{array}$ & 1989 & 1992 & $\underline{\text { www.basel.int }}$ \\
\hline Convention on Biological Diversity & 1992 & 1993 & $\underline{\text { www.cbd.int }}$ \\
\hline $\begin{array}{l}\text { United Nations Convention on the Law of } \\
\text { the Sea (LOS) }\end{array}$ & 1982 & 1994 & $\underline{\text { www.un.org/Depts/los }}$ \\
\hline UN Convention to Comat Desertification & 1994 & 1996 & $\underline{\text { www.unccd.int }}$ \\
\hline
\end{tabular}




\begin{tabular}{|l|c|c|c|}
\hline $\begin{array}{l}\text { in Those Countries Experiencing Serious } \\
\text { Drought and / or Desertification, } \\
\text { Particularly in Africa }\end{array}$ & & \\
\hline $\begin{array}{l}\text { Stockholm Convention on Persistent } \\
\text { Organic Pollutants (POPs) }\end{array}$ & 2001 & 2004 & $\frac{\text { www.chem.unep.ch/po }}{\text { ps }}$ \\
\hline $\begin{array}{l}\text { Kyoto Protocol to the UN Framework } \\
\text { Convention on Climate Change }\end{array}$ & 1998 & 2005 & $\underline{\text { www.unfccc.int }}$ \\
\hline
\end{tabular}

Source: [Dauvergne, 2011:460]

The International Organization for Standardization has developed fourteen thousand voluntary environmental standards series that have adopted by consensus of 148 countries and 154,600 firms.

The Global Environment Facility (GEF) was established as a pilot project on the eve of the Conference on Environment and Development in 1991. It acquired its permanent status in 1994 after three institutions, the World Bank, the United Nations Development Program and the United Nations Environment Program, officially founded it. The GEF Board consists of 14 donor countries and 18 recipient countries. The Facility is open to non-governmental organizations. It finances global environmental programs, mainly in developing countries, including depletion of the ozone layer, biodiversity, climate change and persistent organic pollutants. GEF contributes to the implementation of almost 2,500 projects in 165 countries. The total amount of grants in 2009 exceeded $\$ 8.6$ billion.

As mentioned above, the issue of environmental protection in the work of the WTO is of prime importance. In particular, regulations on environmental issues have been included in the WTO Agreement on Technical Barriers to Trade and Agreement on Sanitary and Phytosanitary measures. These measures protect the life and health of humans, animals and plant life from the growing risks associated with 'pests and diseases' or with 'additives, contaminants, toxins or disease-vector organisms'. In addition, the Agreement on Technical Barriers to Trade includes measures on genetically modified organisms, the prevention of potential threats to biodiversity from genetically modified plants and seeds. The WTO Trade and Environment Committee also explores the interaction between the various environmental rules formulated by the WTO to eliminate contradictions and duplication.

Particular attention is paid to the relationship between multilateral environmental agreements (MEAs) containing trade restrictions. To this end, coordination and cooperation between the WTO Secretariat and international environmental organizations, in particular UNEP, is being implemented.

Discussions on the problem of trade in environmental services were launched during the Uruguay Round of the GATT, when 38 WTO member countries undertook individual sewage obligations (29 items), sanitary and related services (30 items) and some other segments of environmental services.

The negotiation process for the trade in services began in January 2000 and continued in November 2001 within the Doha Round. The central negotiating body is the WTO Council on Trade in Services. The main environmental services, according to the OECD / Eurostat classification, include air pollution control, water management, solid waste management, soil remediation and purification, noise reduction and vibration, environmental research and development, environmental commitments and engineering, analytical services, data processing, analysis and evaluation, education, training, and information. However, the lack of an internationally recognized list of environmental services, as well as a similar list of environmental goods, hinders the process of regulating trade in environmental services. The controversial nature of the negotiation process for the classification of environmental goods is presented schematically in Fig. 1. 


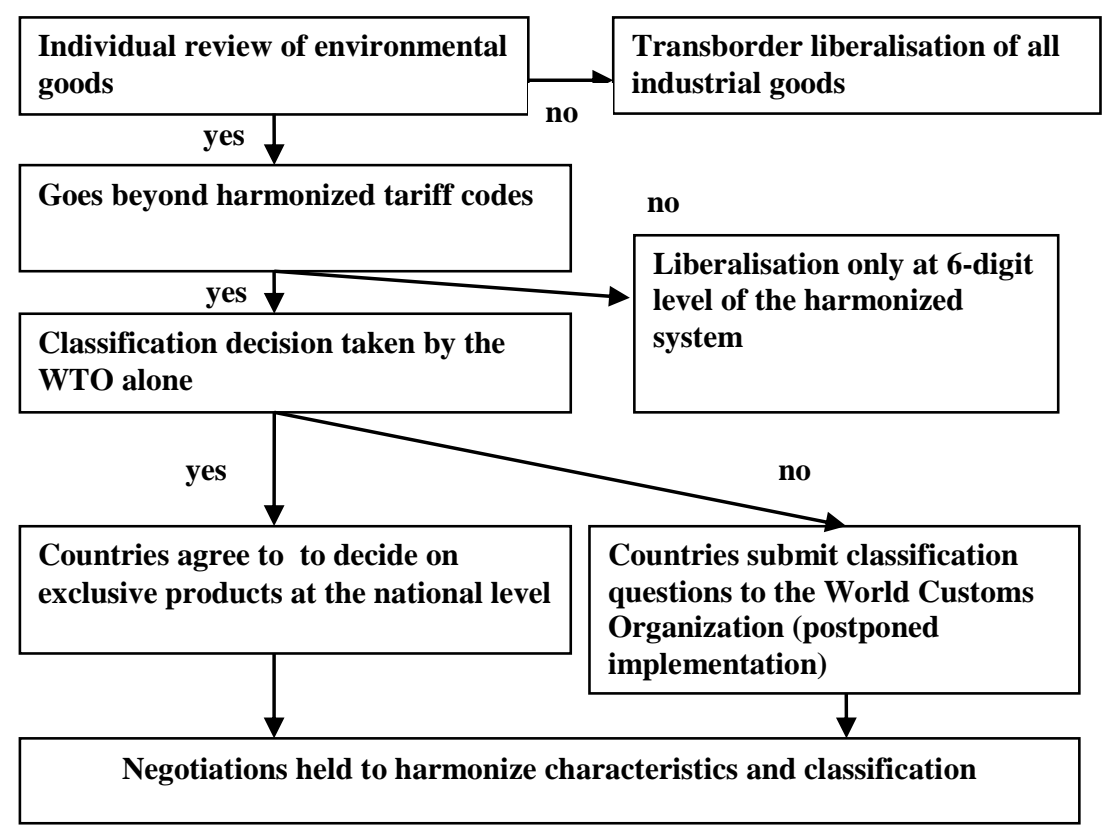

Fig. 1. Negotiations on environmental goods: the classification issue Source: [Steenblik, 2006:85]

The unresolved issue of classification of environmental goods complicates trade and economic relations between countries, endangers operations of companies with green profile, and may harm the environment and health of people. Consequently, there is a need to consider these problems when developing and applying adequate instruments of international environmental policy.

\section{References.}

1. Dauvergne P. (2011). Globalization and the Environment in: Global Political Economy / ed. by J. Ravenhill. - Oxford University Press.

2. Kronberger R., Hofer R. (2012) Österreichische Wirtschaftspolitik. Eine anwendungsorientierte Einführung. - Wien.

3. Lee E.S. (2012) World Trade Regulations. International Trade under the WTO mechanism. - Berlin-Heidelberg.

4. OECD Environmental Outlook to 2030 (2008). - Paris.

5. Smith P.J. (2014) Global Trade Policy: Questions and Answers. - Singapore, 2014.

6. Steenblik R(2006) Liberalising Trade in "Environmental goods": Some Practical Considerations in: Trade that Benefits the Environment and Development.- OECD, Paris. 